\title{
PCNA and Ki67 expression in breast carcinoma: Correlations with clinical and biological variables
}

\author{
E Leonardi, S Girlando, G Serio, F A Mauri, G Perrone, S Scampini, P Dalla Palma, \\ M Barbareschi
}

in fixed samples of breast cancers are limited and contradictory. ${ }^{46}$

The potential value of a proliferation marker like PCNA, which can be applied to routinely fixed specimens, prompted us to evaluate its expression in a series of 106 unselected, untreated breast cancers. The aim was to evaluate the relation between the PCNA labelling index (PCNA-LI) and the $\mathrm{Ki67}$ labelling index (Ki67-LI), and their relation with clinicopathological variablesoestrogen/progesterone receptor content, ${ }^{1}$ and altered expression of the p53 gene..$^{7-10}$

\section{Methods \\ TUMOUR TISSUE}

One hundred and six unselected human breast cancer specimens from untreated patients were collected at surgery, snap-frozen in liquid nitrogen, and stored at $-80^{\circ} \mathrm{C}$. A second parallel sample was fixed in formalin for 24 hours and a third one was fixed in Methacarnoy; both were subsequently processed using routine techniques and paraffin wax embedded. Ninety six cases were infiltrating ductal carcinomas and 10 were infiltrating lobular carcinomas. Tumour size, lymph node state, histological grade (classified according to the modified Bloom and Richardson method for the 96 ductal carcinomas, ${ }^{11}$ and mitotic count (mitoses per 10 high power fields, counted according to Baak) ${ }^{12}$ were recorded for each case. Mitotic counts were started in the most active areas of the neoplasms where the number of mitoses was highest. Once started, nine additional contiguous fields were randomly selected. In selected cases four sets of 10 high power fields were examined and the highest score was recorded as the mitotic index. The axillary lymph nodes had been removed in 95 cases.

\section{PCNA AND KI67 IMMUNOSTAINING}

The PC10-murine IgG2 anti-PCNA monoclonal antibody ${ }^{5}$ (Novocastra Laboratories) was used on formalin and Methacarnoy fixed sections at 1 in 400 and 1 in 800 dilutions, respectively, with overnight incubation at $4^{\circ} \mathrm{C}$. The site of the antibody binding was visualised with the streptavidin-peroxidase labelled method (StrAviGen Super Sensitive Concentrated Detection System; Biogenex Laboratories). Ki67 (Dako) was used on frozen sections at a 1 in 150 dilution for one hour at room temperature; biotinylated anti-mouse IgG ( 1 in 200, Vector, Burlingame, California, USA) and the avidin-biotin complex ( 1 in 100, antibodies against PCNA, which work on routinely fixed specimens have been developed recently. ${ }^{5}$ But the data on PCNA expression 
Vector, Burlingame) were added in sequence.

PCNA and Ki67 immunostainings were scored by counting at least 500 cells in more than 10 high power representative fields. Every stained nucleus was considered positive, irrespective of intensity. In cases where staining was heterogeneous in the tumour, examined fields included those with the highest and those with the lowest percentage of stained cells. Tumours were independently scored by two observers. The percentage of positive stained cells was recorded as the PCNA labelling index and the Ki67 labelling index (LI).

\section{OESTROGEN AND PROGESTERONE RECEPTOR CONTENT}

Frozen sections were immunostained with monoclonal anti-receptor antibodies (oestrogen and progesterone receptor immunocytochemical assay, ER-ICA and PgR-ICA kits; Abbott Laboratories, Chicago, Illinois, USA). The immunostaining was assessed on the basis of the visually estimated percentage of neoplastic cells with positive nuclear staining and on staining intensity. All cases with negative staining and those with less than $10 \%$ of stained cells were regarded as negative.

\section{P53 GENE EXPRESSION}

The monoclonal antibody PAb $1801^{13}$ (Oncogene Science, Manhassett, New York, USA) was used for the immunolocalisation of p53 protein. Frozen sections were air dried, fixed in cold methanol and acetone, and incubated for two hours at room temperature with the primary antibody, at a 1 in 200 dilution. Biotinylated anti-mouse IgG and avidin-biotin peroxidase complex (ABC) were added in sequence (Vectastain ABC Kit; Vector).

Statistical analyses were performed using the Microstat statistical software (Ecosoft, Inc) run on an Olivetti 286 PC.

Frequency tables were tested for association using the $\chi^{2}$ test. The correlations between the PCNA-LI, Ki67-LI, and mitotic count were evaluated using Spearman's rank correlation coefficient.

\section{Figure $1 \quad$ Ki67} immunoreactivity in infiltrating ductal breast carcinoma. Staining is both nuclear and nucleolar ( $A B C$ method with light nuclear counterstain).

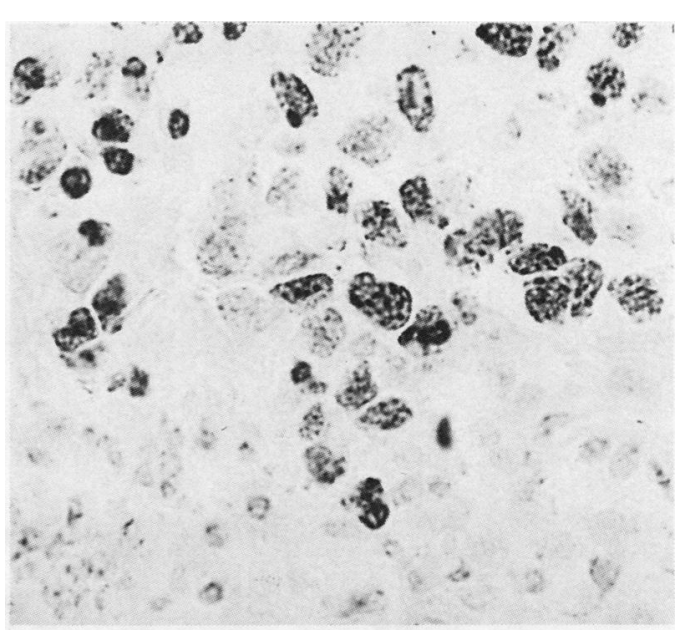

Figure 2 PCNA immunoreactivity in infiltrating ductal breast carcinoma, with predominant granular immunoreactivity (streptavidin biotin labelled method with light nuclear counterstain).

\section{Results}

Ki67 immunostaining was nuclear and nucleolar (fig 1). PCNA immunostaining was clearly evident as granular (in Methacarnoy fixed specimens) or homogeneous (in formalin fixed specimens) nuclear staining (fig 2). Staining intensity was variable, and minor degrees of intratumoural heterogeneity were seen.

p53 protein overexpression was seen in 27 $(25.5 \%)$ cases. Most positive cases (21) showed nuclear immunostaining in all or nearly all malignant cells (fig 3). Six other cases showed only single carcinoma cells with clear nuclear immunoreactivity. These staining patterns agree with the results of Bartek et al. ${ }^{9}$ The percentage of positive cases is somewhat lower than that reported by Bartek et al. ${ }^{9}$

Median and mean mitotic count and labelling index values for $\mathrm{Ki} 67$ and PCNA (on formalin and on Methacarnoy fixed specimens) are reported in table 1 . Median values were used to subdivide lesions in high and low labelled groups. Results are summarised in tables 2 and 3.

The PCNA-LI on formalin fixed specimens correlated with that on Methacarnoy fixed specimens $\left(r_{s}=0.45, p<0.001\right)$, but neither of them correlated with the Ki67-LI or mitotic count (Spearman's rank correlation coefficients are shown in table 4). The PCNA-LI (both on formalin fixed and on Methacarnoy fixed specimens) was not associated with grading, tumour size, nodal state, receptor content, and p53 aberrant gene expression.

The Ki67-LI was positively correlated with mitotic count $(p<0.001)$ (table 4) and was associated with grade $(p<0.001)$ but not with tumour size nor with nodal state. A low Ki67-

Table 1 Mitotic count, Ki67-LI, and PCNA-LI on formalin and Methacarnoy fixed specimens

\begin{tabular}{lll}
\hline & Mean $(S D)$ & Median \\
\hline Mitotic count & $21.52(10.05)$ & 15 \\
Ki67-LI & $14.77(10.09)$ & 13.5 \\
PCNA-LI (F) & $28.72(22.96)$ & 24 \\
PCNA-LI (M) & $59.31(27.09)$ & 55
\end{tabular}

(F) formalin fixed specimens; (M) Methacarnoy fixed specimens. 


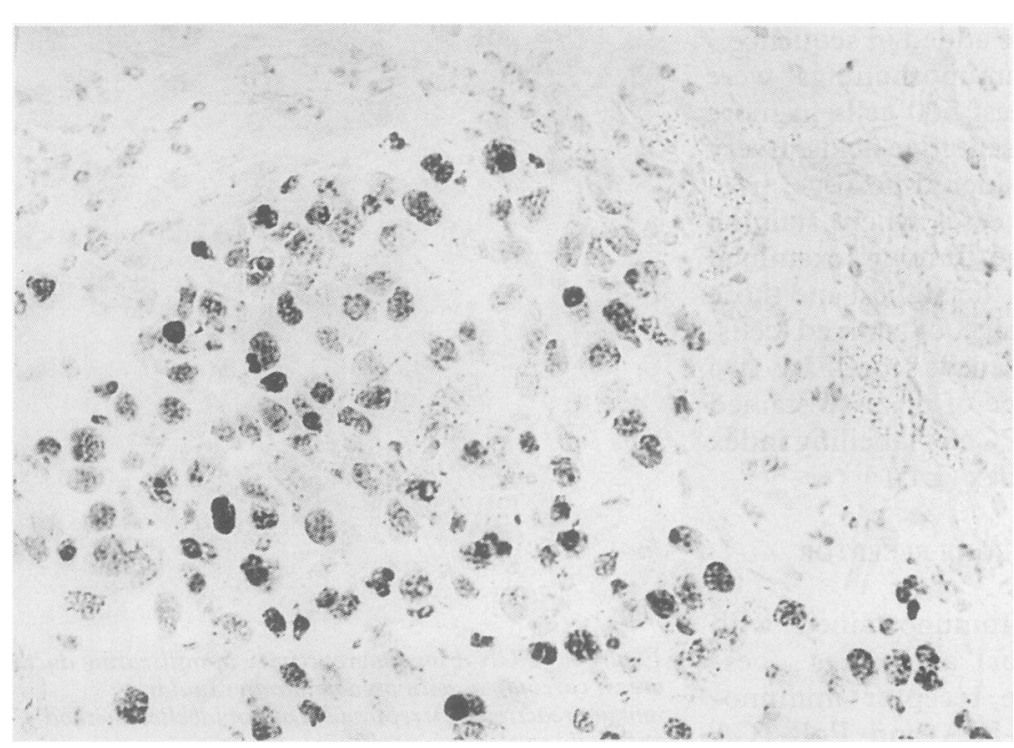

Figure 3 p53 abnormal expression in infiltrating breast carcinoma. Most of the cells are immunoreactive, with different degrees of intensity ( $A B C$ method with light nuclear counterstain).
LI was associated with positive oestrogen and progesterone receptor content $(\mathrm{p}<0.025$ and $\mathrm{p}<0.001$, respectively), and with absence of p53 immunoreactivity $(\mathrm{p}<0.001)$.

\section{Discussion}

The Ki67-LI values agree with the reported mean percentage of $\mathrm{Ki} 67$ labelled cells ranging from $9.4(0.74),{ }^{14} 12(1.49),{ }^{15} 12.5(17 \cdot 6),{ }^{16} 14.5$ $(12 \cdot 9)^{17} 15 \cdot 3(10 \cdot 1),{ }^{18} 16 \cdot 6,,^{19}$ to $20(14 \cdot 48) .^{20}$ Several reports have shown a significant correlation between the Ki67-LI and histological grade of malignancy and mitotic count, and an inverse relation with receptor content, ${ }^{3}$ which has been further confirmed by our study. Tumour size and lymph node state have a controversial association with the Ki67LI, and our findings reinforce the hypothesis of the lack of association. ${ }^{3}$ In our series a strong association between altered expression of the p53 gene and a high Ki67-LI was found, confirming the data of Cattoretti et al. ${ }^{8}$ The p53 gene has a key function in regulating the cell

Table 2 Ki67LI and PCNALI in relation to clinicopathological variables in 106 breast cancers (data for PCNA immunostaining are derived from formalin fixed specimens)

\begin{tabular}{|c|c|c|c|c|}
\hline & Low Ki67LI & High Ki67LI & Low PCNALI & High PCNALI \\
\hline \multicolumn{5}{|l|}{ Grade $^{\star}$ : } \\
\hline $\begin{array}{l}\text { G1 } \\
\text { G2 } \\
\text { G3 }\end{array}$ & $\begin{array}{r}16(16.7 \%) \\
21(21.9 \%) \\
10(10.4 \%) \\
p<\end{array}$ & $\begin{array}{c}2(2 \cdot 1 \%) \\
15(15 \cdot 6 \%) \\
32(33 \cdot 3 \%) \\
1\end{array}$ & $\begin{array}{c}8(8 \cdot 3 \%) \\
14(14.6 \%) \\
25(26.0 \%)\end{array}$ & $\begin{array}{l}10(10 \cdot 4 \%) \\
22(22 \cdot 9 \%) \\
17(17 \cdot 7 \%)\end{array}$ \\
\hline $\begin{array}{l}\text { Tumour size }(\mathrm{cm}) \text { : } \\
<1 \\
1-1 \cdot 5 \\
1 \cdot 6-2 \\
>2\end{array}$ & $\begin{array}{c}6(5 \cdot 7 \%) \\
15(14 \cdot 2 \%) \\
11(10 \cdot 4 \%) \\
24(22 \cdot 6 \%)\end{array}$ & $\begin{array}{c}5(4 \cdot 7 \%) \\
10(9 \cdot 4 \%) \\
16(15 \cdot 1 \%) \\
19(17 \cdot 9 \%)\end{array}$ & $\begin{array}{c}4(3 \cdot 8 \%) \\
12(11 \cdot 2 \%) \\
14(13 \cdot 2 \%) \\
23(21 \cdot 7 \%)\end{array}$ & $\begin{array}{c}7(6 \cdot 6 \%) \\
13(12 \cdot 3 \%) \\
13(12 \cdot 3 \%) \\
20(18 \cdot 9 \%)\end{array}$ \\
\hline $\begin{array}{l}\text { Nodes } \\
\mathbf{N}+ \\
\mathbf{N}-\end{array}$ & $\begin{array}{l}16(16.90 \%) \\
30(31.60 \%)\end{array}$ & $\begin{array}{l}17(17.90 \%) \\
32(33.60 \%)\end{array}$ & $\begin{array}{l}18(18.9 \%) \\
29(30.5 \%)\end{array}$ & $\begin{array}{l}15(15 \cdot 8 \%) \\
33(34 \cdot 8 \%)\end{array}$ \\
\hline
\end{tabular}

Data expressed as the percentage of the total number of cases examined for Ki67 and PCNA immunostaining, respectively.

$\star$ Grade was established only in the 96 infiltrating ductal carcinomas.

$\uparrow$ Node state was examined only in 95 cases. cycle $^{21}$ and is frequently altered in breast cancers. ${ }^{7-10} \mathrm{p} 53$ gene mutations usually lead to the inappropriate accumulation of the p 53 gene product within the nucleus of the cell, reaching the threshold of immunochemical detection. ${ }^{22}{ }^{23}$ Therefore, the demonstration of p53 protein immunoreactivity in tumour sections is indicative of gene alterations and of uncontrolled cell proliferation. ${ }^{23}{ }^{24}$

Our data on the Ki67-LI and PCNA-LI (both on formalin and on Methacarnoy fixed specimens) show no correlation between the two indices. Similar results were found by Barnes et al (unpublished observations cited by Hall $\left.e a l^{4}\right)$. Moreover, our data show that there is no association between the PCNA-LI (both on formalin and Methacarnoy fixed specimens) and histological grade, mitotic count, tumour size and stage, receptor content and altered expression of the $\mathrm{p} 53$ gene. This latter finding suggests that, as far as $\mathrm{p} 53$ gene alterations are concerned, PCNA expression in breast cancer may not be related to changes in the cell cycle.

The lack of association between the PCNALI in breast cancer and several variables, including grade, growth fraction, and altered expression of the cycle controlling p 53 proteins is surprising. PCNA-LI correlates with histological grade ${ }^{25}$ and with growth fraction data obtained using flow cytometry, ${ }^{2627}$ tritiated thymidine incorporation, ${ }^{6}$ bromodeoxyuridine incorporation ${ }^{28}$ and the Ki67 LI. ${ }^{27} 29$

Our data conflict with the reports on PCNA immunostaining in breast cancer made by Dawson $e t \mathrm{al}^{27}$ and Battersby and Anderson. ${ }^{6}$ Dawson et al reported that PCNA positivity correlates with Ki67 immunostaining, with S phase fraction determined by flow cytometry, and with worsening nuclear grade. ${ }^{27}$ Their study was performed with a different antibody (19A2), however, and their cases were analysed on frozen sections. In fact, different results have been obtained using the two different antibodies (PC10 and 19A2) on fixed and frozen sections, respectively, and also in other fields of histopathology - for example, the different results obtained on central nervous system tumours by Louis et $a^{30}$ and Allegranza et al. ${ }^{25}$ If the PCNA-LI gains wide acceptance it will primarily be due to the possibility of being able to use the antibody on routinely processed material, and the above data of Dawson et al would be of little help in this regard. ${ }^{27}$

Battersby and Anderson found a linear correlation between the PCNA-LI and thymidine autoradiography labelling index. ${ }^{6}$ There may be several reasons for their different findings, among which is the antibody used (19A2), the same as Dawson et $a l^{27}$ and especially the fact that they counted only the strongest immunolabelled cells. This procedure, which can be adopted only with the use of an expensive automatic image analyser, may suffer from subjective threshold determination and from the bias of day to day variations in staining intensity.

The lack of correlation between the PCNALI and Ki67-LI, and the lack of association between the PCNA-LI and clinicopathological variables could be attributable to several fac- 
Table 3 Ki67LI and PCNALI in relation to biological variables in breast cancers (data for PCNA immunostaining are derived from formalin fixed specimens)

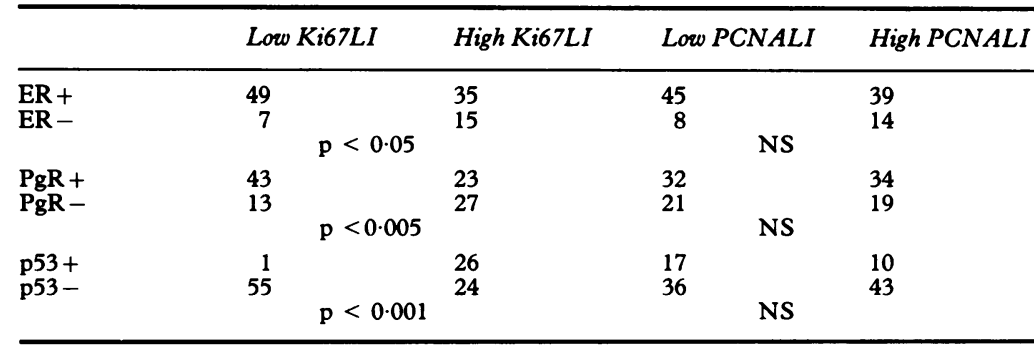

$\mathrm{ER}=$ oestrogen receptor

$\mathrm{PgR}=$ progesterone receptor

Table 4 Spearman's rank correlation coefficients

\begin{tabular}{lllll}
\hline & Ki67-LI & PCNA-LIF & PCNA-LIM & Mitotic count \\
\hline Ki67-LI & & 0.01 & 0.02 & $0.49^{\star}$ \\
PCNA-LIF & 0.01 & $0.45^{\star}$ & $0.45^{\star}$ & 0.23 \\
PCNA-LIM & 0.02 & 0.23 & 0.06 & 0.06 \\
Mitotic count & $0.49^{\star}$ & & \\
\hline
\end{tabular}

(F) Formalin fixed specimens; (M) Methacarnoy fixed specimens.

^Highly significant. proliferating cell nuclear antigen (PCNA). Structural conservation and the detection of a nucleolar form. $J$ Cell Sci 1990;96:121-9.

6 Battersby S, Anderson TJ. Correlation of proliferative activity in breast tissue using PCNA/cyclin. Hum Pathol 1990;21:781.

7 Cattoretti G, Andreola S, Clemente C, D'Amato L, Rilke F. Vimentin and p53 expression on epidermal growth factor receptor-positive, oestrogen receptor-negative breast carcinomas. Br J Cancer 1988;57:353-7.

8 Cattoretti G, Rilke F, Andreola S, D'Amato L, Delia D. p53 expression in breast cancer. Int $J$ Cancer 1988;41:178-83.

9 Bartek J, Bartkova J, Vojtesek B, et al. Patterns of expression of the p53 tumour suppressor in human breast tissues and tumours in situ and in vitro. Int J Cancer 1990;46:839-44.

10 Ostrowsky JL Sawan A. Henry L et al p53 expression in human breat cancer hat to survival and progno in factors: an immunohistochemical study. J Pathol 1991; 164:75-81.

11 Elston CW. Grading of invasive carcinoma of the breast. In: Page DL, Anderson TJ, eds. Diagnostic histopathology of the breast. Edinburgh: Churchill Livingstone, 1987: 300-11.

12 Baak JPA. Mitosis counting in tumors. Hum Pathol 1990; 21:683-5.

13 Banks L, Matlashewskj G, Crawford L. Isolation of human p53-specific monoclonal antibodies and their use in the studies of human p53 expression. Eur J Biochem 1986; 159:529-34.

14 Vielh P, Chevillard S, Mosseri V, Donatini B, Magdelenat H. Ki67 index and S-phase fraction in human breast carcinomas. Am J Clin Pathol 1990;94:681-6.

15 Bouzubar N, Walker KJ, Griffiths K, et al. Ki67 immunostaining in primary breast cancer: pathological and clinical staining in primary breast cancer: patholo

16 Verhoeven D, Bourgeois N, Derde MP, Kaufman L, Buyssens N. Comparison of cell growth in different parts of breast cancers. Histopathology 1990;17:505-9.

17 Veronese S, Gambacorta M. Detection of $\mathrm{Ki}$-67 proliferation rate in breast cancer. Correlation with clinical and pathological features. Am J Clin Pathol 1991;95:30-4.

tors. Primarily, PCNA immunoreactivity is highly sensitive to fixation time, which may alter the real PCNA profile of the neoplasms. Deregulated expression of PCNA and its prolonged half life, which may permit its immunohistochemical detection in cells which have recently left the cell cycle, may also account for some of the above discrepancies. ${ }^{4} 31$ Moreover, PCNA may not only be involved in cell proliferation but also in DNA repair. ${ }^{32}$

In summary, our data suggest that the PCNA-LI is not the same as the Ki67-LI in breast carcinoma. To have a more definitive conclusion about the possible value of PCNA immunostaining in breast cancer, however, further studies are required to evaluate the PCNA-LI in relation to disease free interval and overall survival.

We thank Dr Claudio Doglioni for his valuable suggestions, Dr $M$ Cecilia Fedrizzi for reviewing the English text, and Mrs Piera Paoletto and Mrs Mara Delsanto for their skillful technical assistance.

1 Ellis GK, Gown AM. New applications of monoclonal antibodies to the diagnosis and prognosis of breast cancer. antibodies to the diagnosis and prot

2 Tubiana M, Courdi A. Cell proliferation kinetics in human solid tumors: relation to probability of metastatic, dissemination and long term survival. Radiother Oncol 1989;15:1-18.

3 Brown DC, Gatter KC. Monoclonal antibody Ki67: its use in histopathology. Histopathology 1990;17:489-503.

4 Hall PA, Levison DA, Woods AL, et al. Proliferating cell nuclear antigen (PCNA) immunolocalization in paraffin sections: an index of cell proliferation with evidence of deregulated expression in some neoplasms. J Pathol 1990;162:285-94.

5 Waseem NH, Lane DP. Monoclonal antibody analysis of the
18 Lelle R, Heidenreich W, Stauch G, Gerdes J. The correlation of growth fractions with histologic grading and lymph node status in human mammary carcinoma. Cancer 1987;59:83-8.

19 Gerdes J, Lelle RJ, Pickarts H, et al. Growth fractions in breast cancers determined in situ with monoclonal breast cancers determined in situ with mon

20 Barnard NJ, Hall PA, Lemoine NR, Kadar N. Proliferative index in breast carcinoma determined in situ by $\mathrm{Ki} 67$ immunostaining and its relationship to clinical and pathological variables. J Pathol 1987;152:287-95.

21 Levine AJ, Momad J, Finlay CA. The p53 tumor suppressor gene. Nature 1991;351:453-6. in colorectal cancer. Proc Natl Acad Sci USA 1990;87: 7555-9. expression of mutant forms of p53 oncogene in primary lung cancer. Lancet 1990;335:675-9.

24 Barbareschi M, Girlando S, Mauri FA, et al. Tumor suppressor gene products, proliferation and differentiation markers expression in lung neuroendocrine neoplasms. $J$ Pathol (in press).

25 Allegranza A, Girlando S, Arrigoni GL, et al. PCNA expression in central nervous system neoplasms. Virchows expression in central nervous system neop

26 Garcia RL, Coltrera MD, Gown AM. Analysis of proliferative grade using anti-PCNA/cyclin monoclonal antibodies in fixed, embedded tissues. Am J Pathol 1989;134:733-9.

27 Dawson AE, Norton JA, Weinberg DS. Comparative assessment of proliferation and DNA content in breast carcinoma by image analysis and flow cytometry. Am J Pathol 1990;136:1115-24.

28 Coltrera MD, Gown AM. PCNA/Cyclin expression and BrdU uptake define different subpopulations in different cell lines. J Histochem Cytochem 1991;39:23-30.

29 Levison DA, Hall PA, Woods AL, et al. Evaluation of PCNA (proliferating cell nuclear antigen) immunostaining as a (proliferating cell nuclear antigen) immunostaining as a marker of cell proliferation in formalin-

30 Louis DN, Edgerton S, Thor AD, Hedley-White ET. Proliferating cell nuclear antigen and $\mathrm{Ki} 67$ immunohistochemistry in brain tumors: a comparative study. Acta Neuropathol 1991;81:675-9.

31 Mercer EW, Shield MT, Amin M, et al. Negative growth regulation in a glioblastoma tumor cell line that conditionally expresses human wild-type p53. Proc Natl Acad Sci US A 1990;87:6166-70.

32 Haneda $H$, Katabami $M$, Miyamoto $H$, et al. The relationship of the proliferating cell nuclear antigen protein to CDDP. Oncology 1991;48:234-8.
22 Rodriguez NR, Rowan A, Smith MEF, et al. p53 mutations

23 Iggo R, Gatter K, Bartek J, Lane D, Harris AL. Increased 